Proc. Estonian Acad. Sci. Biol. Ecol., 2003, 52, 4, 423-436

\title{
Influence of light intensity on in vivo fluorescence characteristics of cyanobacteria
}

\begin{abstract}
Aina Leeben
Institute of Ecology, Tallinn Pedagogical University, Kevade 2, 10137 Tallinn, Estonia. Present address: Institute of Marine Systems, Tallinn Technical University, Akadeemia tee 21, 12618 Tallinn, Estonia; aina.leeben@phys.sea.ee

Received 14 November 2002, in revised form 30 May 2003

Abstract. A laboratory experiment was carried out to estimate the extent of changes in fluorescence characteristics of three oscillatorian strains (Planktothrix mougeotii, P. prolifica, and Tychonema bourrellyi) grown in batch culture at two light intensities $\left(9\right.$ and $\left.39 \mu \mathrm{E} \mathrm{m}^{-2} \mathrm{~s}^{-1}\right)$. The following set of measurements was performed in the late log-phase of the growth of the cultures: recording of in vivo fluorescence spectra at $680 \mathrm{~nm}$ by excitation in the range $400-660 \mathrm{~nm}$, determination of chlorophyll $a$ and phycobilin concentrations, cells and trichome numbers, mean cellular volume, and dry weight of the culture. In $T$. bourrellyi and $P$. prolifica the lower light intensity stimulated the synthesis of phycoerythrin, and as a consequence the fluorescence response. Negligible changes in the pigment composition and shape of spectra of the $P$. mougeotii strain were observed. Differences in quantitative fluorescence characteristics normalized to phytoplankton biomass equivalents for cyanobacterial cultures grown at two light intensities are presented.
\end{abstract}

Key words: in vivo fluorescence, cyanobacterial phycobilins, light adaptation, monitoring of cyanobacterial blooms.

\section{INTRODUCTION}

Detection and observation of cyanobacterial blooms have become very topical all around the world. As cyanobacteria contain specific chromoproteins called phycobiliproteins, which have characteristic spectral structures at certain fluorescence excitation/emission co-ordinates (Rüdiger, 1980; Hilton et al., 1989a, b; Schubert et al., 1989; Kaitala et al., 1994; Poryvkina et al., 1994; Wood et al., 1998, 1999), they can be easily detected in vivo by measuring fluorescence spectra. All cyanobacteria contain at least three classes of blue phycobiliproteins: phycocyanin (PC), allophycocyanin (APC), and allophycocyanin B. A number of strains synthesize in addition red phycoerythrin (PE) or less commonly purplish phycoerythrocyanin (Chapman, 1973; Rüdiger, 1980; Carr \& Wyman, 1986). Low chloro- 
phyll (Chl) $a$ emission while excited in its own absorption band at $430-440 \mathrm{~nm}$ is another peculiarity of fluorescence characteristics of cyanobacteria (Fig. 1). Quantitative (not functional) minority of the green pigment in these microorganisms' photosystem II, whose fluorescence dominates at normal temperature, is the reason of the phenomenon (Johnsen \& Sakshaug, 1996). Prochlorophytes, or 'the other cyanobacteria' (Matthijs et al., 1994), form an exceptional group of blue-greens as they do not contain a detectable amount of phycobilins (PhBs) (Pinevich et al., 1999). Their fluorescence spectra are similar to those of green algae having maxima in the Chl $a$ and $b$ absorption range (Fig. 1).

An important step in applying in vivo fluorescence excitation spectra to water ecosystem analysis is moving from measurements of relative concentration of phytoplankton pigments to absolute values. To realize this step, the calibration dependences of fluorescence intensities on the pigment concentrations must be determined. Chl $a$ is the only photopigment routinely determined in marine and freshwater samples.

Just a few attempts have been made to use the $\mathrm{PhB}$ fluorescence signal as an indicator of the abundance of the $\mathrm{PhB}$-containing algal groups in natural water (Cowles et al., 1993; Lee et al., 1994; Poryvkina et al., 1994; Seppälä \& Balode, 1998; Babichenko et al., 1999). Such rare use of in vivo fluorometry in the detection of cyanobacteria could have the following reasons:

1. The lack of a simple and reliable field technique to estimate PhBs' concentration hampers routine quantification of the $\mathrm{PhBs}$ ' fluorescence signal in the processing of natural phytoplankton samples (Stewart \& Farmer, 1984;

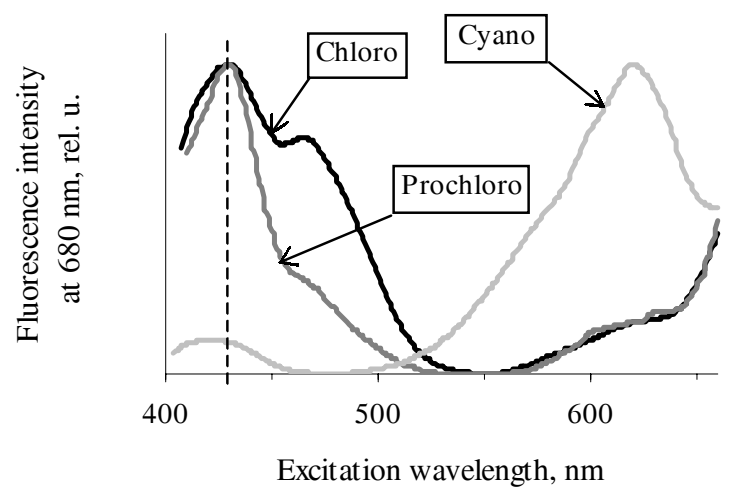

Fig. 1. Examples of in vivo fluorescence excitation spectra of algal and cyanobacterial monocultures from the culture collection of the Norwegian Institute for Water Research. Spectra are normalized to a maximum intensity in the spectrum. The dashed line marks an approximate excitation wavelength used widely in single-fixed-wavelength fluorometers for the determination of chlorophyll $a$ fluorescence as a measure of this pigment concentration. Chloro $=$ Chlorophyceae (Pseudokirchneriella subcapitata, strain CHL 1); Cyano = Cyanophyceae (Pseudanabaena limnetica, strain NIVA-CYA 276/6); Prochloro = Prochlorophyceae (Prochlorothrix scandica, strain 5/89). 
Wyman, 1992). The main problem in the quantification of $\mathrm{PhBs}$ is to disrupt effectively a variety of cyanobacterial cells and achieve a complete extraction of the pigments as the cell walls of some blue-greens are extremely resistant to chemical and physical treatments (Rowan, 1989). On the other hand, care has to be taken not to overtreat samples; besides, they have to be handled in cold and dark as high temperature and intense light could degrade PhBs in extract (Moreth \& Yentsch, 1970; Downes \& Hall, 1998).

2. The quantity and quality of light can have a major effect on blue-greens, changing the pigment content, and as a consequence the fluorescence response (Hilton et al., 1989b). Alteration of $\mathrm{PhB}$ composition due to changes in light quality is well documented (Bennett \& Bogorad, 1973; Bogorad 1975; Tandeau de Marsac, 1977). The phenomenon called complementary chromatic adaptation has not been observed in all cyanobacteria. Among those cyanobacteria that do not adapt chromatically to light quality picoplanktonic species have been reported (Carr \& Wyman, 1986). Results of some studies suggest that the influence of light quantity on the pigment composition of cyanobacteria is also species-specific (Bryant, 1982; Carr \& Wyman, 1986).

Although the response of pigment composition and concentration in cyanobacteria to quantitative and qualitative changes in light conditions has been investigated rather thoroughly, less is known of changes and the range of variations of in vivo fluorescence characteristics of blue-greens under different light conditions. The aim of the experiment reported here was to study the influence of light intensity on the quantitative and qualitative fluorescence characteristics of cyanobacteria. Measurements of in vivo fluorescence, pigment content, and biomass represented in cell and trichome numbers, cellular volume (on its basis calculation of cell carbon content is possible), and dry weight were carried out on three strains of cyanobacteria - Planktothrix mougeotii, P. prolifica, and Tychonema bourrellyi - to estimate the extent of variations of concentration-specific fluorescence characteristics under different light conditions. These potentially toxin-producing oscillatorians chosen for the experiment form dense blooms in eutrophic waters (Watanabe, 1979; Skulberg \& Skulberg, 1985; Laugaste, 1986; Skulberg, 1999). The results obtained in the laboratory experiment can serve to provide a correct interpretation and quantitative transformation of fluorescence data registered during cyanobacterial blooms.

\section{MATERIAL AND METHODS \\ Strains and growth conditions}

Cyanobacterial strains from the algae culture collection of the Norwegian Institute for Water Research (NIVA) were used in the experiment. Detailed information on the strain isolated is given in Table 1. Precultures were grown in modified culture medium Z8 (Skulberg, 1990) at light intensity $6 \mu \mathrm{E} \mathrm{m}^{-2} \mathrm{~s}^{-1}$ during 3 weeks. Fluorescent lamps (Philips TL 65W/33) were used for illumination. Cyanobacteria were cultivated on a shaking table at $18^{\circ} \mathrm{C}$. 
Table 1. Information on the strains (isolated by R. Skulberg)

\begin{tabular}{ccccc}
\hline Species & Strain designation & Geographical origin & Year \\
\hline Planktothrix mougeotii & NIVA-CYA 278 & $\begin{array}{l}\text { Lake Steinsfjorden, } \\
\text { Buskerud, Norway }\end{array}$ & 1989 \\
Planktothrix prolifica & NIVA-CYA 98 & $\begin{array}{c}\text { Lake Steinsfjorden, } \\
\text { Buskerud, Norway }\end{array}$ & 1982 \\
Tychonema bourrellyi & NIVA-CYA 33/1 & $\begin{array}{c}\text { Lake Mjøsa, } \\
\text { Akershus, Norway }\end{array}$ & 1976
\end{tabular}

For the experiment, an inoculate $(20 \mathrm{~mL})$ was added to $1 \mathrm{~L}$ of the above medium solution. The cultures were maintained under two light intensities: at 9 (D culture) and $39 \mu \mathrm{E} \mathrm{m}^{-2} \mathrm{~s}^{-1}$ (L culture). The samples for analyses were collected on the late log-phase of the growth of the cultures estimated by fluorescence intensity and Chl $a$ concentration.

\section{Fluorescence measurements}

The in vivo excitation spectra of algae in the range 400-660 $\mathrm{nm}$ at the emission wavelength $680 \mathrm{~nm}$ were measured in a standard quartz cuvette with a spectrofluorimeter FluoImager 32B (Skalar). The spectral maxima measured for cyanobacteria reflect mainly the intensity of light emitted from Chl $a$ by excitation of the PhBs; the corresponding maxima in the spectra are referred to as "Chl $a$ fluorescence (at excitation around $430 \mathrm{~nm}$ ), PE fluorescence (at excitation around $550 \mathrm{~nm}$ ), and PC fluorescence (at excitation around $620 \mathrm{~nm}$ )". Culture samples with very high densities were diluted with culture medium before analysis. As the aim of the experiment was to analyse the relative changes in spectral features, no fluorescence spectral quantum correction was performed. Pigment-specific fluorescence was determined by normalizing the fluorescence intensity to the respective pigment concentration.

\section{Pigment analysis}

For the analysis of the amount of pigments $\left(C_{\text {pigment }}\right)$ algal cells were collected by filtration on a glass fibre filter (type GF/F, Whatman) under suction pressure. $\mathrm{Chl} a$ concentration was measured in methanol extracts previously clarified by centrifugation at $49500 \mathrm{~g}$ (outer row) for $1 \mathrm{~h}$ at $4{ }^{\circ} \mathrm{C}$. In vitro absorption spectra were recorded with a UV-VIS scanning spectrometer Lambda 40 (Perkin Elmer). Absorptivity of 78.0 $\mathrm{L} \mathrm{g}^{-1} \mathrm{~cm}^{-1}$ given by Talling \& Driver (cited in Arvola, 1981) was used for the calculation of Chl $a$. For the determination of PhBs' concentrations cells were resuspended in $50 \mathrm{mM}$ phosphate buffer $(\mathrm{pH}$ 6.75) and disrupted by sonication (VirSonic 300, Virtis Company) with a sonicator output of $60 \mathrm{~W}$. The sonicator was run for $1 \mathrm{~min}$ by $20 \mathrm{~s}$ cycles with a $20 \mathrm{~s}$ break interval between the 

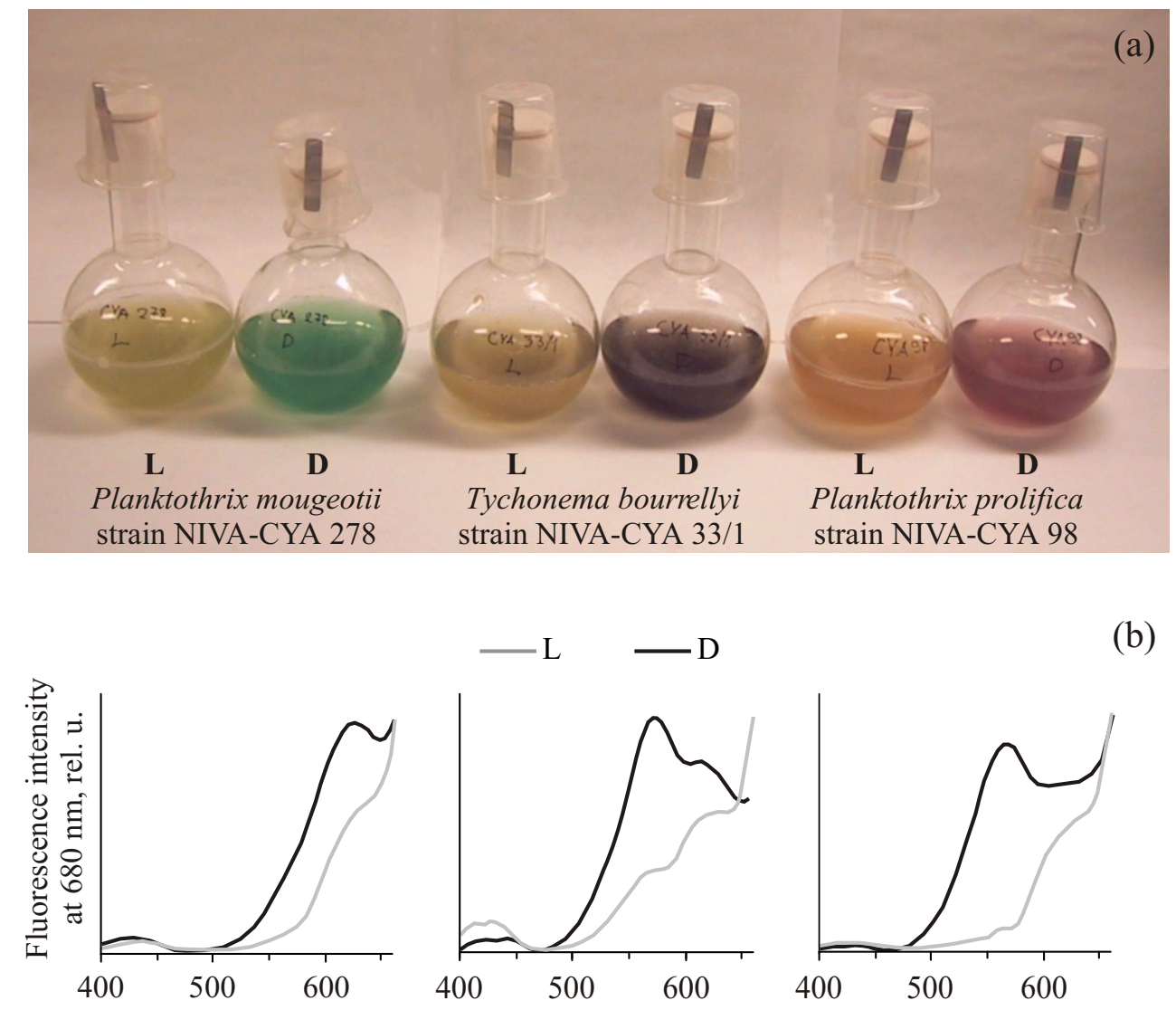

(b)
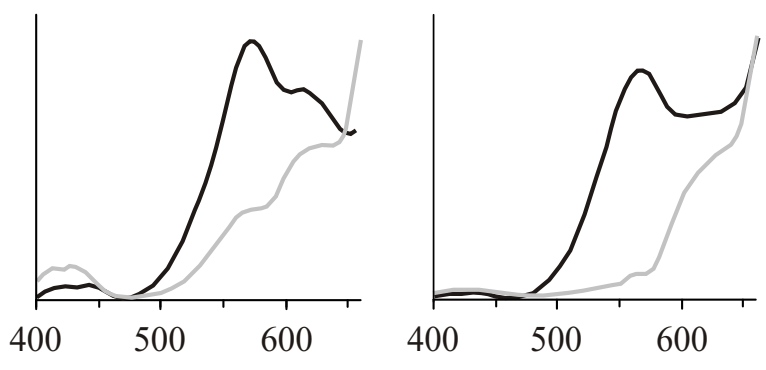

Excitation wavelength, nm
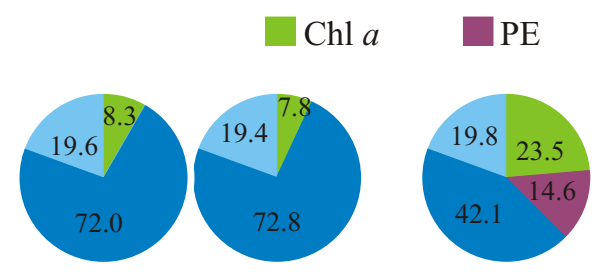

$\square \mathrm{PC}$

APC

(c)

Fig. 2. Experiment on three cyanobacterial monocultures cultivated at two light intensities ( 39 and $9 \mathrm{i} \mathrm{E} \mathrm{m} \mathrm{s}^{-1}$, in the figures L and D cultures, respectively). Differences in coloration (a), shape of in vivo fluorescence excitation spectra (b), and pigment content, \% (c). Figures are placed under the corresponding culture in the photo. The photo was taken after 13 days of cultivation at different light illumination. Spectra and pigment concentration were obtained for all dark cultures on the 18th, for the L culture of NIVA-CYA 278 on the 11th, for the L culture of NIVA-CYA 33/1 on the 12th, and for the L culture of NIVA-CYA 98 on the 15th day after the start of the experiment. Fluorescence excitation spectra are scaled to a maximum intensity. The fluorescence maxima of excitation spectra correspond to the direct excitation of Chl $a$ (in the violet spectral band) and its excitation through accessory pigments (phycoerythin in yellow, phycocyanin in orange, and allophycocyanin in the red spectral band). Concentrations of cyanobacterial carotenoids, which serve mainly a photoprotective function, were excluded. Chl $a=$ chlorophyll $a$; PE = phycoerythrin; $\mathrm{PC}=$ phycocyanin $; \mathrm{APC}=$ allophycocyanin . 
runs to avoid heating up the extract solution. During all manipulations the tubes with extracts were kept in an ice bath. Before spectrophotometrical readings the extracts were clarified by centrifugation (at $51000 \mathrm{~g} 4 \mathrm{~h}$ at $4^{\circ} \mathrm{C}$ ). The concentrations of $\mathrm{PhB}$ were calculated according to Bennett \& Bogorad (1973).

\section{Dry weight determination}

The aliquots of cultures were filtered through a previously weighed glass fibre filter (type GF/C, Whatman). The filters were placed in a drying oven four $2 \mathrm{~h}$ at $104^{\circ} \mathrm{C}$. After that filters were reweighed and the dry weight $(D W)$ of cyanobacterial cells in the aliquot was calculated.

\section{Microscopic analysis}

Cyanobacterial cells were preserved with Lugol solution. Cells and trichome (tr) numbers were counted by a light microscope. The average volume of the cyanobacterial cells $\left(V_{\text {cell }}\right)$ was calculated using the stereometrical formula given by Edler (1979).

\section{RESULTS}

The experiment revealed marked differences in the coloration and fluorescence properties of cyanobacterial strains grown at the lower light intensity (Fig. 2a, b). The contrast in the pigmentation of cultures grown at the higher light was not so strong; however, an increased absorbance of light in the yellow spectral region was a distinctive pattern in the fluorescence excitation spectrum for the L culture of $T$. bourrellyi.

The spectra clearly indicate that P. mougeotii contained C-PC (excitation maximum occurred at $624 \mathrm{~nm}$ ) and its $\mathrm{PhB}$ composition did not change due to light conditions. T. bourrellyi had both types of cyanobacterial PhB: C-PC (maximum at $615 \mathrm{~nm}$ ) and C-PE (peak at $566 \mathrm{~nm}$ ), but the relative intensity of PE fluorescence of this strain cultivated at the higher light was notably lower. The intensity of PE fluorescence (maximum at $569 \mathrm{~nm}$ ) of the $P$. prolifica strain grown at the higher light illumination was very low and substituted for the excitation through PC. Analysis of the pigment concentration (Fig. 2c) showed also an increased portion of PE content in the D cultures of $T$. bourrellyi and P. prolifica. The red pigment in $P$. prolifica differed in its absorption properties from PE of T. bourrellyi (Fig. 3).

Changes caused by different light in cell and trichome level are given in Table 2. Higher number of cells and longer trichomes compared with $L$ cultures were characteristic features for all $\mathrm{D}$ cultures. In the $\mathrm{L}$ cultures of $T$. bourrellyi and $P$. prolifica cells were larger than in the respective D cultures, contrary to the cultures of $P$. mougeotii. 


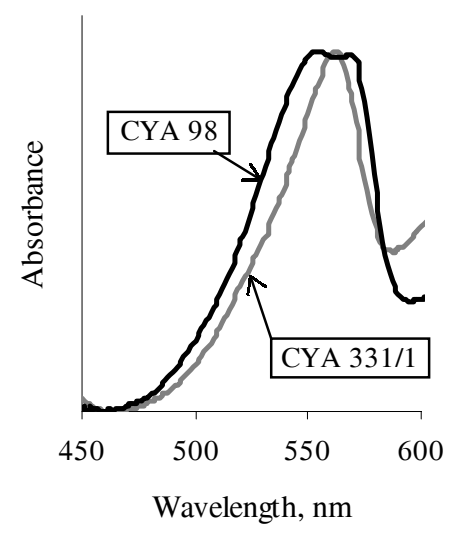

Fig. 3. Differences in absorption properties of phycoerythrins in phosphate buffer (pH 6.75) isolated from cyanobacterial strains Tychonema bourrellyi (CYA 33/1) and Planktothrix prolifica (CYA 98) grown at $9 \mu \mathrm{E} \mathrm{m}^{-2} \mathrm{~s}^{-1}$. Peaks at 554, 568 (CYA 33/1), and $562 \mathrm{~nm}$ (CYA 98).

The main changes in quantitative fluorescence characteristics of the oscillatorian strains studied are summarized in Table 3 . These data show that light intensity had a very low influence on the pigment-specific fluorescence of the $P$. mougeotii strain, but the pigments fluorescence calculated per cell, cellular volume, and trichome for the $\mathrm{D}$ culture was somewhat higher than in the $\mathrm{L}$ culture.

Cultivation of $T$. bourrellyi at the higher light illumination caused a significant drop in pigments-specific fluorescence. Miscellaneous behaviour of pigments fluorescence per biomass equivalents was observed: the lower light caused a decrease in the values for Chl $a$ fluorescence. The corresponding parameters of $\mathrm{PhBs}$ were higher for the D culture, with the exception of PC fluorescence determined per cell. It should be noted that differences between $\mathrm{D}$ and $\mathrm{L}$ cultures of PE fluorescence per biomass equivalents were approximately 2-fold higher than the corresponding values for PC.

Table 2. Changes in cell densities, trichome numbers, mean cellular volume, and mean trichome length of three cyanobacterial cultures grown at 39 (L) and $9 \mu \mathrm{E} \mathrm{m}^{-2} \mathrm{~s}^{-1}$ (D)

\begin{tabular}{|c|c|c|c|c|c|c|c|c|c|}
\hline \multirow[t]{2}{*}{ Characteristic } & \multicolumn{3}{|c|}{ Planktothrix mougeotii } & \multicolumn{3}{|c|}{ Tychonema bourrellyi } & \multicolumn{3}{|c|}{ Planktothrix prolifica } \\
\hline & $\mathrm{L}$ & $\mathrm{D}$ & $\mathrm{D} / \mathrm{L}$ & $\mathrm{L}$ & $\mathrm{D}$ & $\mathrm{D} / \mathrm{L}$ & $\mathrm{L}$ & $\mathrm{D}$ & $\mathrm{D} / \mathrm{L}$ \\
\hline Cell numbers $\mu \mathrm{L}^{-1}\left(10^{3}\right)$ & 3.8 & 6.8 & 1.8 & 2.0 & 10.1 & 5.1 & 4.1 & 9.0 & 2.2 \\
\hline Mean cell volume, $\mu \mathrm{m}^{3}$ & 49.1 & 61.3 & 1.3 & 110.4 & 54.5 & 0.5 & 95.8 & 69.6 & 0.7 \\
\hline Trichome numbers $\mu \mathrm{L}^{-1}$ & 40.0 & 33.3 & 0.8 & 65.2 & 112.2 & 1.7 & 143.0 & 19.6 & 0.1 \\
\hline $\begin{array}{l}\text { Mean trichome length, } \\
\text { mm }\end{array}$ & 0.24 & 0.64 & 2.7 & 0.08 & 0.25 & 3.1 & 0.09 & 1.05 & 11.7 \\
\hline
\end{tabular}


Table 3. Differences in the concentration-specific fluorescence characteristics and fluorescence ratios for cyanobacterial cultures grown at 39 (L) and $9 \mu \mathrm{E} \mathrm{m}^{-2} \mathrm{~s}^{-1}(\mathrm{D})$. Pigment and dry matter concentration $-\mathrm{mg} \mathrm{L}^{-1}$; cell and trichome concentration - number per L; cellular volume $-\mu \mathrm{m}^{3}$

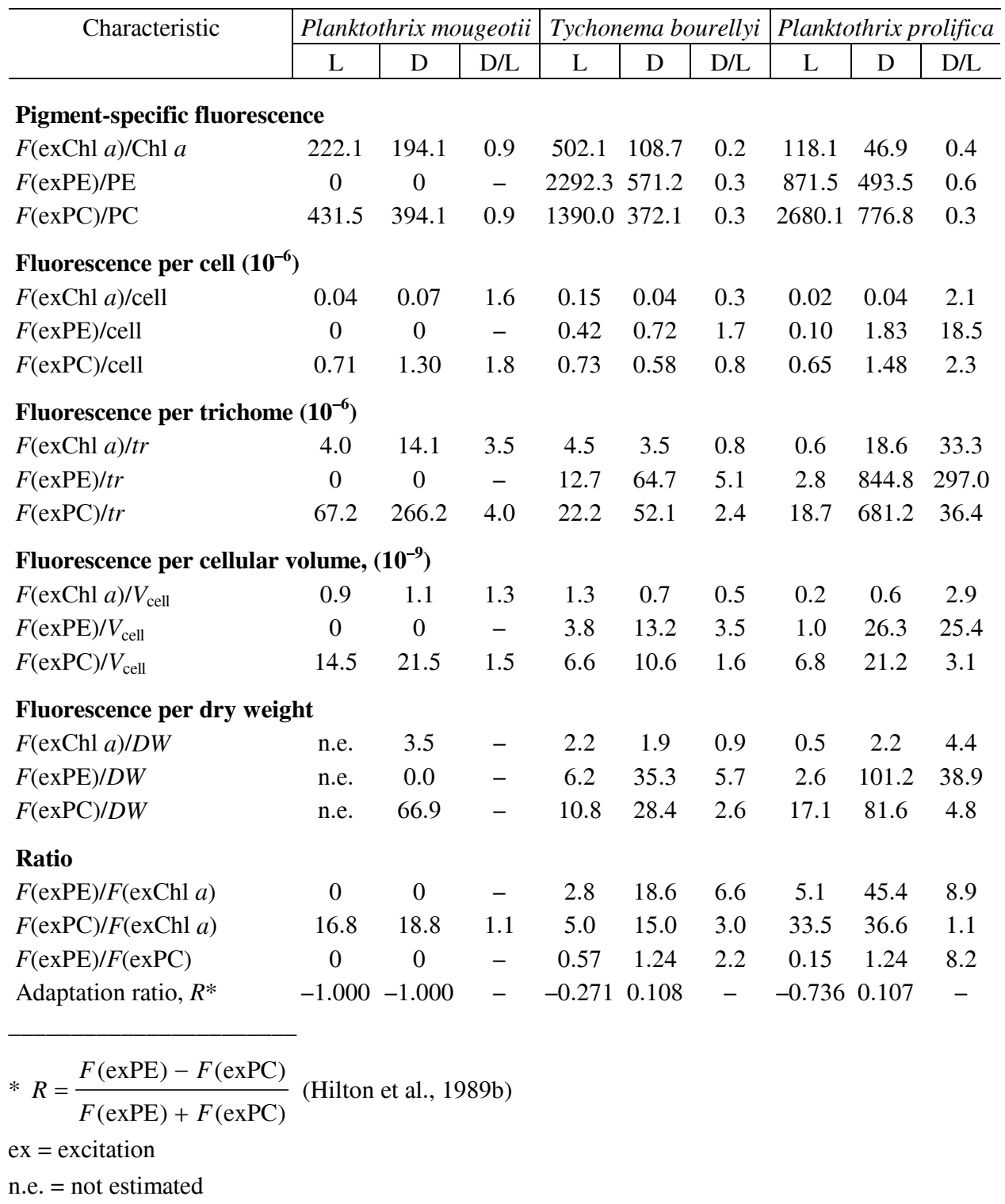

In the D culture of $P$. prolifica the pigment-specific fluorescence was also lower than in the $\mathrm{L}$ culture. All fluorescence calculations per biomass varied in a similar way: the light intensity of $9 \mu \mathrm{E} \mathrm{m}^{-2}$ led to an increase in the values, while changes for the PE values (D/L) were 8-9-fold as high as the differences in the corresponding values for $\mathrm{Chl} a$ and PC. 


\section{DISCUSSION}

The influence of light intensity of $9 \mu \mathrm{E} \mathrm{m}^{-2} \mathrm{~s}^{-1}$ on the pigmentation and fluorescence spectra of two cyanobacterial strains $-T$. bourrellyi and $P$. prolifica - was similar to the effect of green light stimulating the synthesis of PE contrary to $39 \mu \mathrm{E} \mathrm{m}^{-2} \mathrm{~s}^{-1}$, which like red light, reduced its synthesis in cells. On the whole, variation of fluorescence excitation spectra can be described using the chromatic adaptation ratio, $R$ (Table 3 ), suggested by Hilton et al. (1989b). Theoretically $R$ will vary from +1 to -1 , respectively, when Chl $a$ fluorescence at $680 \mathrm{~nm}$ is stimulated by $\mathrm{PE}$ excitation or by $\mathrm{PC}$ only. Comparison of $R$ values for T. bourrellyi grown at intensities 9 and $39 \mu \mathrm{E} \mathrm{m}^{-2} \mathrm{~s}^{-1}$ in the experiment (Table 3) with $R$ values calculated by Hilton et al. (1989b) for Oscillatoria bourrellyi $\left(=T\right.$. bourrellyi) cultivated at 21 and $388 \mu \mathrm{E} \mathrm{m}^{-2} \mathrm{~s}^{-1}(R$ values 0.513 and 0.233 , respectively) indicates that changes in fluorescence excitation spectra caused by different illumination are strain-specific and depend also on the photoacclimation status of cells.

As some blue-greens can produce PE, they are able to develop stable populations at depths where the light level is even less than $1 \%$ of surface illumination (Skulberg, 1999). However, cyanobacteria can be exposed to very high irradiances when they float up, or when they are passively carried up to the surface by vertical mixing processes in the water cplanktolumn. According to Demeters et al. (1991), physiological responses of phytoplankton to light fluctuations involve several mechanisms, observed as changes in (1) the fluorescence yield, (2) the size and density of photosynthetic units, (3) the composition and distribution of pigments, and (4) the chemical composition and activity of photosynthetic enzymes. These mechanisms respond at different rates and may depend on such factors as previous light and nutrient history of phytoplankton cells, the range of light intensity, light shift, and length of the exposition time (Prézelin \& Matlick, 1983; Prézelin et al., 1986).

In the experiment the light conditions varied in a small range; with increasing culture density the actual level of light intensity certainly dropped even lower than the ambient illumination, especially for D cultures. A larger variation of light intensity can have a stronger effect on the fluorescence characteristics of cyanobacteria.

The higher illumination led to an augmentation of pigment-specific fluorescence indicating a decline in photosynthetic activity in the L cultures; the coloration and shortened trichomes of L cultures also point to unfavourable light conditions for these cyanobacteria strains. The L culture of P. mougeotii reacted to the higher light most drastically collapsing suddenly on the 11th day of the experiment. The collapse of the culture was determined from very low fluorescence intensity and extracted $\mathrm{Chl} a$ concentration; visually no changes in the culture colour were observed. However, according to Vila \& Abella (2001), who investigated lightharvesting adaptation of planktonic phototrophic microorganisms in natural conditions, cyanobacteria rich in PC occupy an upper position in the water column compared to PE-containing cyanobacteria, which are dominant in deep metalimnia 
(deeper than 8-10 m). Hence, P. mougeotii should endure higher light intensities better than red cyanobacteria.

Depending on the type and aim of investigations, different expressions of the fluorescence signal $(F)$ in algal biomass units can be used. The experiment showed that differences in the concentration-specific fluorescence for $\mathrm{D}$ and $\mathrm{L}$ cultures $(\mathrm{D} / \mathrm{L})$ increased in the following order (for comparison corresponding values for Chl $a$ fluorescence are also given):

P. mougeotii

Chl $a$, PC: $\quad F / C_{\text {pigment }} \rightarrow F / V_{\text {cell }} \rightarrow F /$ cell $\rightarrow F / t r$

T. bourrellyi

Chl $a: \quad F / D W \rightarrow F / t r \rightarrow F / V_{\text {cell }} \rightarrow F /$ cell $\rightarrow F / C_{\text {pigment }}$

PE: $\quad F /$ cell $\rightarrow F / C_{\text {pigment }} \rightarrow F / V_{\text {cell }} \rightarrow F /$ tr $\rightarrow F / D W$

PC: $\quad F /$ cell $\rightarrow F / V_{\text {cell }} \rightarrow F / t r \rightarrow F / D W \rightarrow F / C_{\text {pigment }}$

P. prolifica

Chl $a: \quad F /$ cell $\rightarrow F / V_{\text {cell }} \rightarrow F / C_{\text {pigment }} \rightarrow F / D W \rightarrow F /$ tr

PE: $\quad F / C_{\text {pigment }} \rightarrow F /$ cell $\rightarrow F / V_{\text {cell }} \rightarrow F / D W \rightarrow F / t r$

PC: $\quad F /$ cell $\rightarrow F / V_{\text {cell }} \rightarrow F / C_{\text {pigment }} \rightarrow F / D W \rightarrow F /$ tr

This means that by converting the fluorescence signal from the cyanobacterial cells with different light adaptation status to biomass units, dispersion of data could be minimal for biomass equivalents represented at the beginning of the above-given series. Therefore, transformation of the fluorescence signal to the corresponding pigment concentration is widely used. However, high correlation between the fluorescence intensity of $\mathrm{PhBs}$ and the abundance of some cyanobacteria, expressed either by cell number or cellular volume, can also be achieved.

\section{CONCLUSIONS}

Information on the variability of the fluorescence of phycobilin pigments is important when excitation spectra of in vivo fluorescence are used in environmental studies. The illumination experiment on three strains of oscillatorians clearly demonstrated high variability and multi-directional changes of concentrationspecific fluorescence characteristics in response to different light intensities. In this study changes in only phycoerythrin and phycocyanin were analysed. Registration of the Chl $a$ fluorescence excitation spectrum further in the infrared region will allow recording the portion of $\mathrm{Chl} a$ fluorescence stimulated also by allophycocyanin. Considering this additional spectral part in analysis, it will be possible to distinguish spectrally more cyanobacterial (sub)groups, not only the $\mathrm{PE}$ and PC fluorescence group. As a result, an enhanced detection and identification of dominant species/groups of cyanobacterial blooms in automatic mode could be achieved. 


\section{ACKNOWLEDGEMENTS}

This experiment and a part of the analyses were carried out at the Norwegian Institute for Water Research (NIVA). I am very grateful to the whole staff of the institute for hospitality and the opportunity to use laboratory facilities. My special thanks are due to Dr. Olav Skulberg and Torsten Källqvist for valuable theoretical and practical advice. I gratefully acknowledge Randi Skulberg for help in handling algal cultures. I also wish to thank my colleagues from the Institute of Ecology at Tallinn Pedagogical University Elga Rull for microscopic analysis of samples and Dr. Kai Künnis for valuable comments during preparation of the manuscript. I am very grateful to Prof. Jiři Komárek (Institute of Botany, Academy of Sciences of Czeck Republic) for encouragement and helpful discussion. The suggestions of two anonymous reviewers improved the paper considerably. This study was supported by the Research Council of Norway (grant IS-OE9 77/99) and the Estonian Science Foundation (grant 4714).

\section{REFERENCES}

Arvola, L. 1981. Spectrophotometric determination of chlorophyll $a$ and phaeopigments in ethanol extractions. Ann. Bot. Fenn., 18, 221-227.

Babichenko, S., Kaitala, S., Leeben, A., Poryvkina, L. \& Seppälä, J. 1999. Phytoplankton pigments and dissolved organic matter distribution in the Gulf of Riga. J. Mar. Syst., 23, 69-82.

Bennett, A. \& Bogorad, L. 1973. Complementary chromatic adaptation in a filamentous blue-green alga. J. Cell Biol., 58, 419-435.

Bogorad, L. 1975. Phycobiliproteins and complementary chromatic adaptation. Ann. Rev. Plant Physiol., 26, 369-401.

Bryant, D. A. 1982. Phycoerythrocyanin and phycoerythrin: properties and occurrence in cyanobacteria. J. Gen. Microbiol., 128, 835-844.

Carr, N. C. \& Wyman, M. 1986. Cyanobacteria: their biology in relation to the oceanic picoplankton. Can. Bull. Fish. Aquatic. Sci., 214, 159-204.

Chapman, D. J. 1973. Biliproteins and bile pigments. In The Biology of Blue-green Algae (Carr, N. G. \& Whitton, B. A., eds.), pp. 162-185. Univ. California Press, Berkeley.

Cowles, T. J., Desidero, R. A. \& Neuer, S. 1993. In situ characterization of phytoplankton from vertical profiles of fluorescence emission spectra. Mar. Biol., 115, 217-222.

Demeters, S., Roy, S., Gagnon, R. \& Vignault, C. 1991. Rapid light-induced changes in cell fluorescence and in xanthophyll-cycle pigments of Alexandrium excavatum (Dinophyceae) and Thalassiosira pseudonana (Bacillariophyceae): a photo-protective mechanism. Mar. Ecol. Prog. Ser., 76, 185-193.

Downes, M. T. \& Hall, J. A. 1998. A sensitive fluorimetric technique for the measurements of phycobilin pigments and its application to the study of marine and freshwater picophytoplankton in oligotrophic environments. J. Appl. Phycol., 10, 357-363.

Edler, L. (ed.). 1979. Recommendations for marine biological studies in the Baltic Sea. Phytoplankton and chlorophyll. Baltic Mar. Biol., 5.

Hilton, J., Rigg, E. \& Jaworski, G. 1989a. Algal identification using in vivo fluorescence spectra. J. Plankton Res., 11, 65-74.

Hilton, J., Rigg, E. \& Jaworski, G. 1989b. In vivo algal fluorescence, spectral change due to light intensity changes and the automatic characterization of algae. Freshwater Biol., 21, 375-382. 
Johnsen, G. \& Sakshaug, E. 1996. Light-harvesting in bloom-forming marine phytoplankton: speciesspecific and photoacclimation. Sci. Mar., 60, 47-56.

Kaitala, S., Babichenko, S., Poryvkina, L. \& Leeben, A. 1994. Fluorescent analysis of pigment composition of natural phytoplankton. Mar. Technol. Soc. J., 28, 50-58.

Laugaste, R. 1986. Punane vesi Juusa järves. Eesti Loodus, 11, 738-740.

Lee, T., Tsuzuki, M., Takeuchi, T., Yokoyama, K. \& Karube, I. 1994. In vivo fluorometric method for early detection of cyanobacterial waterblooms. J. Appl. Phycol., 6, 489-495.

Matthijs, H. C. P., van der Staay, G. W. M. \& Mur, L. R. 1994. Prochlorophytes: the 'other' cyanobacteria? In The Molecular Biology of Cyanobacteria (Bryant, D. A., ed.), pp. 49-64. Kluwer Acad. Publ., Dordrecht.

Moreth, C. M. \& Yentsch, C. S. 1970. A sensitive method for the determination of open ocean phytoplankton phycoerythrin pigments by fluorescence. Limnol. Oceanogr., 15, 313-317.

Pinevich, A. V., Skulberg, O. M., Matthijs, H. C. P., Willén, E., Gavrilova, O. V. \& Velichko, N. 1999. Characterization of a novel chlorophyll $b$-containing Prochlorothrix species (Prochlorophyta) and its photosynthetic apparatus. Microbios, 100, 159-174.

Poryvkina, L., Babichenko, S., Kaitala, S., Kuosa, H. \& Shalapjonok, A. 1994. Spectral fluorescence signatures in the characterization of phytoplankton community composition. J. Plankton Res., 16, 1315-1327.

Prézelin, B. B \& Matlick, H. A. 1983. Nutrient-dependent low-light adaptation in the dinoflagellate Gonyaulax polyedra. Mar. Biol., 74, 141-150.

Prézelin, B. B., Samuelsson, G. \& Matlick, H. A. 1986. Photosystem II photoinhibition and altered kinetics of photosynthesis during nutrient dependent high-light photoadaptation in Gonyaulax polyedra. Mar. Biol., 93, 1-12.

Rowan, K. S. 1989. Photosynthetic Pigments of Algae. Cambridge Univ. Press.

Rüdiger, W. 1980. Plant biliproteins. In Pigments in Plants (Czygam, F. C., ed.), pp. 315-349. Gustav Fischer Verlag, Stuttgart, New York.

Schubert, H., Schiewer, U. \& Tschirner, E. 1989. Fluorescence characteristics of cyanobacteria (blue-green algae). J. Plankton Res., 11, 353-359.

Seppälä, J. \& Balode, M. 1998. The use of spectral fluorescence methods to detect changes in the phytoplankton community. Hydrobiologia, 363, 207-217.

Skulberg, O. M. 1990. Culture Collection of Algae. Catalogue of Strains. Norwegian Institute for Water Research, Oslo.

Skulberg, O. M. 1999. Steinsfjorden. Toksinproduserende blågrønnalger, O-97129. Norsk institutt for vannforskning, Oslo.

Skulberg, O. M. \& Skulberg, R. 1985. Planktic species of Oscillatoria (Cyanophyceae) from Norway. Characterization and classification. Arch. Hydrobiol. Suppl., 71, 157-174.

Stewart, D. \& Farmer, F. 1984. Extraction, identification, and quantitation of phycobiliprotein pigments from phototrophic plankton. Limnol. Oceanogr., 29, 392-397.

Tandeau de Marsac, N. 1977. Occurrence and nature of chromatic adaptation in cyanobacteria. J. Bact., 130, 82-91.

Vila, X. \& Abella, C. A. 2001. Light-harvesting adaptation of planktonic phototrophic microorganisms to different light quality conditions. Hydrobiologia, 452, 15-30.

Watanabe, M. F. 1979. Studies on the metalimnetic blue-green alga Oscillatoria mougeotii in an eutrophic lake with special reference to its population growth. Arch. Hydrobiol., 86, 66-86.

Wood, A. M., Phinney, D. A. \& Yentsch, C. S. 1998. Water column transparency and the distribution of spectrally distinct forms of phycoerythrin-containing organisms. Mar. Ecol. Progr. Ser., 162, 25-31.

Wood, A. M., Lipse, M. \& Coble, P. 1999. Fluorescence based characterization of phycoerythrincontaining cyanobacterial communities in the Arabian Sea during the Northeast and early Southwest Monsoon (1994-1995). Deep-Sea Res., II 46, 1769-1790.

Wyman, M. 1992. An in vivo method for the estimation of phycoerythrin concentration in marine cyanobacteria (Synechococcus spp.). Limnol. Oceanogr., 37, 1300-1306. 


\title{
Valguse intensiivsuse mõju tsüanobakterite in vivo fluorestsentsi karakteristikutele
}

\begin{abstract}
Aina Leeben
Viimastel aastakümnetel on kogu maailmas muutunud aktuaalseks sinivetikate "õitsengute" avastamine, nende leviku ulatuse kindlakstegemine ja biomassi määramine. Sinivetikate ehk tsüanobakterite olemasolu veeproovides on võimalik tuvastada spektraalse fluorestsentsi meetodi abil in vivo. Fluorestsentsi andmete interpreteerimisel peab arvestama, et valgustingimused võivad mõjutada sinivetikate pigmentkoostist ja järelikult ka spektraalkarakteristikuid. Fluorestsentsi karakteristikute muutuste ulatuse hindamiseks korraldati laboratoorne eksperiment kolme liigiga seltsist Oscillatoriales (Planktothrix mougeotii, P. prolifica ja Tychonema bourrellyi), mida kasvatati valguse intensiivsusel 9 ja $39 \mu \mathrm{E} \mathrm{m}^{-2} \mathrm{~s}^{-1}$. Sinivetikate kultuuride hilises kiire kasvu faasis registreeriti spektraalses vahemikus 400-660 nm ergastatud pigmentide in vivo fluorestsents lainepikkusel $680 \mathrm{~nm}$. Paralleelselt määrati klorofüll $a$ ja fükobiliinide kontsentratsioon kultuuris, rakkude ja trihhoomide arvukus, keskmine rakumaht ning kuivaine kogus. Madalamal valgusintensiivsusel kasvatatud $T$. bourrellyi ja $P$. prolifica kultuurides suurenes fükoerütriini kontsentratsioon. Vastavad muutused olid jälgitavad ka fluorestsentsi ergastusspektrites. Planktothrix mougeotii kultuuride pigmentkoostist ja kvalitatiivseid spektraalkarakteristikuid mõjutas valguse intensiivsus vähe. Eksperiment näitas olulisi erinevusi valges ja hämaras kasvatatud sinivetikakultuuride fükobiliinide fluorestsentsi intensiivsuses sõltuvalt kasutatud biomassi ekvivalendist (pigmendi kontsentratsioon, vetikarakkude arvukus jne).
\end{abstract}

